Published by LPMP Imperium

Journal homepage: https:/ / ejournal.imperiuminstitute.org/ index.php/JMSAB

\title{
Strategi manajemen pembentukan badan usaha milik desa (BUM Desa)
}

\author{
Eka Nuraini*, Djunaedi Djafar, Hartian Ramadhan \\ Manajemen Administasi, Akademi Manajemen Belitung
}

JMSAB

183

Paper type

Case Study

Keywords: management strategies, BUM Desa

\begin{abstract}
Abstrak
Berdasarkan studi pendahuluan di Desa Air Saga, masalah yang dihadapi oleh desa untuk membentuk BUM Desa adalah kurangnya kemampuan untuk memetakan potensi desa, sulit menemukan SDMyangakan mengelola BUM Desa, ketidakpahaman untuk memulai pendirian BUM Desa, dan kurangnya kemampuan untuk menyusun kelengkapan administrasi BUM Desa. Permasalahan tersebut harus segeradiatasi dengan melakukan kegiatan penelitian yang bertujuan untuk merumuskan strategi manajemen pembentukan BUM Desa khususnya di Desa Air Saga. Penelitian menggunakan metode kualitatif dengan melakukan observasi, wawancara kepada kepala desa dan BPD, dan FGD. Data yang terkumpulkan dianalisis dengan teknik deskriptif kualitatif. Hasil penelitian menunjukkan bahwa strategi agresif adalah strategi yang tepat untuk membentuk BUM Desa di Desa Air Saga Kecamatan Tanjungpandan Kabupaten Belitung. Pelaksanaan strategi pembentukan BUM Desa harus melibatkan pendamping desa dan dievaluasi dalam setiap kegiatannya.
\end{abstract}

*Email korespondensi: ekanuraini@amb.ac.id

Pedoman Sitasi: Nuraini, E., Djafar, D., \& Ramadhan, H. (2019Strategi manajemen pembentukan badan usaha milik desa (BUM Desa). Jurnal Manajemen Strategi dan Aplikasi Bisnis, 2(2), 183 - 192
Received: 22 Oct 2019

Revised: 27 Nov 2019

Accepted: 05 Dec 2019

Online: 06 Dec 2019

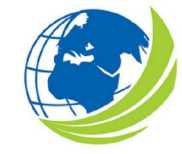

Jurnal Manajemen Strategi dan Aplikasi Bisnis, Vol 2, No.2, Agustus 2019, pp. 183 - 192

eISSN 2655-237X 


\section{PENDAHULUAN}

BUM Desa termasuk salah satu dari empat program prioritas terkait penggunaan dana desa. BUM Desa dikelola oleh desa yang diharapkan dapat meningkatkan pendapatan desa untuk mensejahterakan masyarakat desa. Berdasarkan Peraturan Pemerintah No. 43 Tahun 2014 (PP Desa) disebutkan bahwa BUM Desa adalah suatu badan usaha yang dimiliki oleh desa dengan modal baik sebagian maupun seluruhnya dari kekayaan desa guna mengelola aset, jasa pelayanan, dan usaha lainnya untuk kesejahteraan masyarakat desa.

Berdasarkan data dari Bidang Pemerintahan Desa di Badan Pemberdayaan Masyarakat, Pemerintahan Desa, Perempuan dan KB Kabupaten Belitung, bahwa pada tahun 2018 ada 50\% dari 42 desa di Kabupaten Belitung yang belum memiliki BUM Desa. Kendala yang dihadapi oleh desa untuk membentuk BUM Desa adalah kesulitan memetakan potensi desa, kesediaan pengelola yang memiliki kompetensi untuk mengelola BUM Desa, ketidakpahaman untuk memulai pendirian BUM Desa, dan kurangnya kemampuan untuk menyusun kelengkapan administrasi BUMDesa.

Desa Air Saga adalah salah satu desa di Kecamatan Tanjung Pandan yang berada cukup dekat dengan pusat kota dan merupakan daerah pesisir pantai. Pada tahun 2018, desa ini belum memiliki BUM Desa. Padahal eksistensi BUM Desa sebagai lembaga ekonomi sudah diakui sejak tahun 2004, dan peraturan perundangan yang membahas lebih rinci tentang BUM Desa tersedia pada tahun 2014. Jadi, Desa Air Saga cukup tertinggal dalam pembentukan BUM Desa.

Berdasarkan studi pendahuluan di Desa Air Saga, permasalahan yang dihadapi oleh desa Air Saga untuk membentuk BUM Desa adalah kemampuan awal desa untuk memanajemen pembentukan BUM Desa. Desa kesulitan mengidentifikasi keunggulan desa yang bisa dijadikan objek usaha dalam BUM Desa. Letak Desa Air Saga yang dekat dengan pusat kota semakin memperkuat kesulitan desa untuk menentukan unit usaha yang akan dijalankan dalam BUM Desa karena banyak usaha-usaha seperti toko bangunan, kuliner, fashion, dan sebagainya yang menjadi pesaing BUM Desa sehingga dikhawatirkan akan memperlemah eksistensi BUM Desa. Oleh karena itu, BUM Desa Air Saga perlu unit usaha yang unik dan benar-benar dibutuhkan oleh masyarakat sekitar serta mampu berdaya saing kuat dengan usaha-usaha yang sudah ada di pusat kota Tanjungpandan.

Permasalahan yang lainya adalah kesulitan desa untuk mendapatkan SDM yang memiliki kompetensi untuk menjalankan BUM Desa. Sama halnya dengan desa lainnya, ada kekhawatiran desa terhadap kualitas pengurus BUM Desa baik dari segi kompetensinya maupun kepribadiannya. BUM Desa akan terlaksana dengan baik dan mencapai tujuan yang diharapkan jika dikelola oleh SDM yang berkompetensi memanajemen usaha, namun berlahan akan menjadi hancur jika SDM tidak memiliki kepribadian yang jujur, adil, dan perhatian terhadap usaha ekonomi desa. Oleh sebab itu, pemasalahan SDM juga perlu menjadi perhatian setelah desa mampu mengidentifikasi potensi desa yang strategis untuk dijadikan unit usaha desa.

Berdasar hasil kajian penelitian yang relevan tentang BUM Desa, penelitian ini memiliki topik yang terkini karena permasalahan yang paling mendasar tentang BUM Desa adalah masalah manajemen. Di Kabupaten Belitung, banyak desa yang belum mampu mendirikan BUM Desa karena pemahaman tentang manajemen masih kurang. BUM Desa yang sudah terbentuk juga mengalami permasalahan manajemen sehingga usaha yang dijalankan kurang memiliki kelengkapan administrasi dan lemah fungsi kontrolingnya. Oleh sebab itu, dalam rangka mensukseskan program pemerintah untuk kesejahteraan desa, maka penelitian ini mengkaji strategi manajemen BUM Desa supaya Desa Air Saga mampu membentuk BUM Desa. Strategi 
Manajemen dari hasil kegiatan penelitian diharapkan bisa menjadi refrensi bagi desa lain yang kesulitan untuk membentuk BUMDesa.

\section{KAJIAN PUSTAKA}

\section{Badan Usaha Milik Desa}

BUM Desa dalam Undang-Undang No.32 Tahun 2004 tentang Pemerintahan Daerah dan PeraturanP emerintahNo.72 Tahun 2005 tentang Desa dimaksudkan sebagai usaha desa untuk mendorong dan menampung seluruh kegiatan peningkatan pendapatan masyarakat, baik yang berkembang menurut adat istiadat dan budaya setempat, maupun kegiatan perekonomian yang diserahkan untuk dikelola oleh masyarakat.

Dalam Permendagri No.39 Tahun 2010 tentang BUM Desa, kepemilikan modal dan pengelolaan BUM Desa dilakukan oleh pemerintahdesadanmasyarakat.BUM Desadibentuk atas dasar kebutuhan dan potensi desadalam upaya memperkuat perekonomian desa. Berdasarkan hal tersebut, pemerintah desa perlu memiliki kemampuan dalam menganalisis potensi desa supaya bisa menjadi unit usaha untuk menciptakan sebuah kemajuan dalam masyarakat.

Murdani(2017) menjelaskan bahwa potensi desa merupakan seluruh sumber daya yang dimiliki oleh desa, dimanfaatkan untuk kelangsungan perkembangan desa. Ada dua potensi desa yaitu potensi fisik dan potensi nonfisik. Sumber daya berupa potensi fisik adalah tanah, air, manusia, cuaca, iklim, dan ternak. Sedangkan sumberdaya yang termasuk potensi nonfisik yaitu masyarakat desa, aparatur desa atau pamong desa, dan lembaga sosial desa. Penjelasan lebih lanjut tentang BUM Desa diatur dalam Peraturan Menteri Desa, Pembangunan Daerah Tertinggal, dan Transmigrasi Republik Indonesia Nomor 4 Tahun 2015 tentang Pendirian, Pengurusan dan Pengelolaan, dan Pembubaran Badan Usaha Milik Desa. Berdasarkan Permendes tersebut, pendirian BUM Desa dimaksudkan sebagai upaya menampung seluruh kegiatan dibidang ekonomi dan/atau pelayanan umum yang dikelola oleh desa dan/atau kerjasama antar-Desa. Artinya, desa bisa bekerjasama dengan desa lain untuk mengelola usaha-usaha secara bersama.

\section{Strategi Manajemen}

Pengertian strategi dalam Kamus Besar Bahasa Indonesia adalah ilmu dan seni dalam memanfaatkan semua sumber daya bangsa untuk melaksanakan kebijaksanaan tertentu dalam perang dan damai. Berdasarkan pengertian tersebut, makna strategi dalam sebuah organisasi adalah ilmu dan seni dalam memanfaatkan semua sumber daya yang ada dalam organisasi untuk melaksanakan kebijakan tertentu dalam menjalankan organisasi untuk mencapai tujuan.

Manajemen menurut Sule dan Saefullah (2015) merupakan seni atau proses dalam menyelesaikan sesuatu untuk mencapai tujuan. Siswanto (2005) juga mendefinisikan manajemen sebagai ilmu dan seni melakukan tindakan untuk untuk mencapai tujuan yang diinginkan. Berdasarkan pengertian strategi dan manajemen maka dapat dirumuskan pengertian strategi manajemen yaitu ilmu dan seni menggunakan semua sumber daya organisasi untuk melaksanakan kebijakan tertentu dalam menyelesaikan sesuatu untuk mencapai tujuan.

Rizka Hayyuna et al. (2014) mengungkapkan teori tentang strategi manajemen oleh David J Hunger dan Thomas L.Wheelen, bahwa strategi manajemen memiliki dasar pokok meliputi: (1) Mengamati lingkungan (enviromental scanning). Kegiatan yang dilakukan dalam mengamati lingkungan adalah monitoring faktor internal dan eksternal organisasi dengan mengkaji SWOT yaiut kekuatan (strength), kelemahan (weakness), kesempatan (opportunity) dan ancaman (threaths). (2) Penyusunan strategi (strategy formulation). Hal yang dilakukan dalam menyusun strategi adalah pengembangan rencana jangka panjang seperti penentuan visi dan misi, tujuan yang akan dicapai. Namun dalam kasus ini, penyusunan strategi yang dikembangkan adalah strategi pembentukan BUM Desa sehingga yang dilakukan adalah menentukan strategi dari hasil analisis SWOT yang diwujudkan dalam suatu prosedur sebagai pedoman dalam melakukan kegiatan pembentukan organisasi BUM 
Desa. (3) Pelaksanaan strategi (strategy implementation). Pelaksanaan strategi merupakan penerapan kebijakan-kebijakan yang telah ditentukan melalui pengembangan program, budget, dan prosedur. (4) Evaluasi atau kontrol. Tahap ini dilakukan untuk mengetahui apakah suatu organisasi berjalan sesuai dengan strategi yang telah disusun. Kegiatan yang dilakukan pada tahap ini adalah pengawasan internal dan eksternal. Keempat tahap strategi manajemen ini, jika dijalankan dengan benar akan membentuk organisasi, dalam hal ini adalah BUM Desa yang memiliki kekuatan manajemen untuk mencapai tujuannya.

\section{METODE}

Penelitian merupakan penelitian kualitatif yang ditujukan untuk mendeskripsikan strategi manajemen pembentukan BUM Desa Air Saga untuk tahun 2019. Penelitian dilaksanakan di Desa Air Saga, Kecamatan Tanjungpandan, Kabupaten Belitung, Provinsi Kepulauan Bangka Belitung. Subjek penelitian ditentukan dengan teknik puposive sampling. Subjek penelitian berjumlah 19 orang yang terdiri darisatu orang kepala desa, tiga orang tokoh masyarakat, 12 orang ketua RT, dan tiga orang perwakilan organisasi masyarakat.

Teknik pengumpulan data yang digunakan dalam penelitian ini adalah wawancara dan observasi, sehingga instrumen penelitian yang digunakan adalah pedoman wawancara dan lembar observasi. Indikator penelitian yang digunakan adalahenviromental scanning, strategy formulation, strategy implementation, dan evaluasi atau kontrol.

Data yang terkumpul akan dianalisis dengan teknik deskriptif kualitatif. Untuk meningkatkan tingkat kepercayaan terhadap penelitian ini maka dilakukan uji kredibilitas data dengan memperpanjang proses pengamatan untuk kejelian dan ketekunan dalam penelitian, triangulasi, dan diskusi dengan teman sejawat (Sugiyono, 2013). Berdasarkan analisis data akan ditarik kesimpulan dan mengajukan saran/rekomendasi kepada pihak-pihak yang berkepentingan dengan pembentukan BUM Desa Air Saga.

\section{HASIL DAN PEMBAHASAN Mengamati lingkungan}

Mengamati lingkungan bertujuan mendapatkan gambaran potensi desa dengan melihat kekuatan, kelemahan, kesempatan, dan ancaman sehingga dapat diketahui strategi yang bisa dirumuskan untuk membentukBUM Desa.Berdasarkan hasil wawancara dengan Kepala Desa, ada kendala dalam mendirikan BUM Desa yaitu kesulitan menentukan usaha yang tepat. Selain kesulitan menentukan usaha, kelemahan dalam perencanaan pendirian BUM Desa adalah belum ada Peraturan Desa tentang BUM Desa sebagai payung hukum pendirian BUM Desa. Ada rencana desa untuk mendirikan BUM Desa, namun belum terwujud karena BPD belum menyelesaikan Perdes tentang BUM Desa. Informasi lebih lanjut bahwa Kepala Desa melimpahkan seluruh tanggungjawab perencanaan pendirian BUM Desa kepada BPD. Kondisi ini menunjukkan kurangnya sinergi antara Kepala Desa dengan BPD dalam perencanaan pembentukanBUM Desa. Salah satu fungsi BPD adalah melakuan pembahasan Rancangan Peraturan Desa bersama Kepala Desa, kemudian menyepakatinya bersama-sama. Oleh sebab itu penyusunan Perdes tentang BUM Desa seharusnya dilakukan secara bersama-sama antara BPD dan Kepala Desa.

Untuk menemukan data yang lebih lengkap tentang lingkungan maka dilakukan pertemuan FGD yang menghadirkan perangkat desa, BPD, ketua RT, tokoh masyarakat dan usaha, dan organisasi masyarakat. Dari hasil FDG diperoleh informasi bahwa ada lahan sawah milik masyarakat yang potensial dijadikan unit usaha sebagai tempat pariwisata dan hutan mangrove di pinggir jalan umum yang merupakan jalur akses wisata di Pulau Belitung. Peserta FGD menunjukkan keyakinan untuk menjadikan dua potensi desa ini sebagai usaha desa yang menjanjikan keuntungan dan 
kesejahteraan desa. Dari kegiatan FGD juga dihasilkan kesepakatan masyarakat untuk mendirikan BUM Desa di desa Air Saga selambat-lambatnya pada tahun 2020.

Berikut ini matrik SWOT setelah mendapatkan data dari wawancara, observasi, dan FGD.

Tabel 1. Matrik SWOT Lingkungan

\begin{tabular}{|c|c|c|}
\hline Faktor eksternal & $\begin{array}{ll}\text { Peluang-Opportinity }(\mathrm{O}) \\
\text { 1. } & \begin{array}{l}\text { Perkembangan sektor } \\
\text { pariwisata di Pulau }\end{array} \\
\text { Belitung } \\
\text { 2. } & \begin{array}{l}\text { Dukungan pemerintah dan } \\
\text { stakeholder lainnya }\end{array}\end{array}$ & $\begin{array}{l}\text { Ancaman-Threat }(\mathrm{T}) \\
\text { 1. Lokasi desa yang } \\
\text { dekat dengan } \\
\text { perkotaan } \\
\text { menyebabkan } \\
\text { banyaknya pesaing } \\
\text { usaha/ bisnis }\end{array}$ \\
\hline $\begin{array}{ll}\text { Kekuatan-Strenght (S) } \\
\text { 1. } & \begin{array}{l}\text { Komitmen desa untuk } \\
\text { membentuk BUM Desa }\end{array} \\
\text { 2. } & \begin{array}{l}\text { BPD pernah mengikuti } \\
\text { pelatihan BUM Desa, studi }\end{array} \\
\text { banding } \\
\text { 3. Desa memiliki potensi laut } \\
\text { dan pertanian } \rightarrow \text { produk } \\
\text { unggulan: barang } \\
\text { kerajinan dari kerang, } \\
\text { olahan makanan laut, } \\
\text { beras merah } \\
\text { 4. Desa memiliki lahan } \\
\text { sawah dan hutan } \\
\text { mangrove }\end{array}$ & $\begin{array}{l}\text { Strategi SO } \\
\text { 1. Menentukan bidang usaha } \\
\text { yang berhubungan dengan } \\
\text { sektor pariwisata yang } \\
\text { bisa menjadi central untuk } \\
\text { memasarkan produk } \\
\text { unggulan desa yaitu } \\
\text { agrowisata sawah dan } \\
\text { hutan mangrove } \\
\text { 2. Memanfaatkan dukungan } \\
\text { pemerintah dan } \\
\text { stakeholder lainnya untuk } \\
\text { membentuk BUM Desa }\end{array}$ & $\begin{array}{l}\text { Strategi ST } \\
\text { 1. Memanfaatkan } \\
\text { pengalaman dari } \\
\text { kegiatan pelatihan } \\
\text { dan studi banding } \\
\text { untuk } \\
\text { merencanakan } \\
\text { usaha sektor } \\
\text { pariwisata yang } \\
\text { lebih kreatif dan } \\
\text { inovatif }\end{array}$ \\
\hline 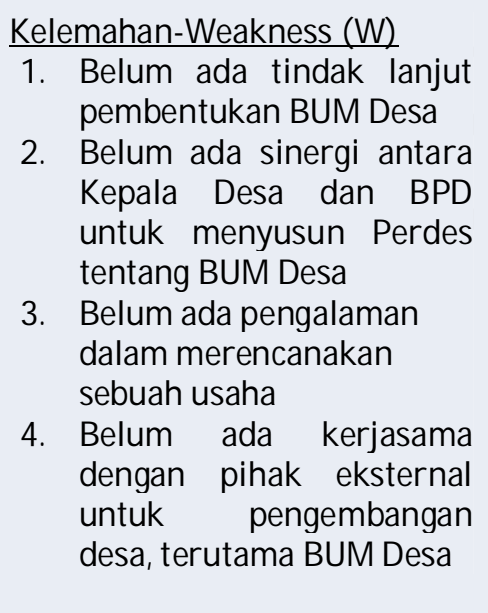 & \begin{tabular}{l}
\multicolumn{1}{c}{ Strategi W-O } \\
1. Memanfaatkan dukungan \\
pemerintah dan \\
stakeholder lainnya untuk \\
mendampingi Kepala Desa \\
dan BPD dalam \\
penyusunan Perdes dan \\
perlengkapan lainnya \\
untuk mendirikan BUM \\
Desa. \\
2. Menjalin kerjasama \\
dengan pihak eksternal \\
untuk mendirikan BUM \\
Desa
\end{tabular} & $\begin{array}{l}\quad \text { Strategi W-T } \\
\text { Menjalin kerjasama } \\
\text { dengan pihak eksternal } \\
\text { untuk meningkatkan } \\
\text { wawasan dan } \\
\text { pengetahuan tentang } \\
\text { perencanaan sebuah } \\
\text { usaha dalam bentuk } \\
\text { pelatihan dan } \\
\text { pendampingan }\end{array}$ \\
\hline
\end{tabular}

\section{Penyusunan Strategi Pembentukan BUM Desa}

Data lingkungan yang terekam dalam tabel SWOT dianalisis untuk mengetahui strategi untuk pembentukan BUM Desa. Berikut ini hasil analisis SWOT. 
Tabel 2. Analisis SWOT Strategi Pendirian BUM Desa

\begin{tabular}{|c|c|c|c|}
\hline Kekuatan-Strenght (S) & Skor & Kelemahan-Weakness (W) & Skor \\
\hline $\begin{array}{ll}\text { a. } & \text { Komitmen desa untuk } \\
\text { membentuk BUM Desa } \\
\text { b. } \\
\text { BPD pernah mengikuti } \\
\text { pelatihan BUM Desa, studi } \\
\text { banding } \\
\text { c. Desa memiliki potensi laut dan } \\
\text { pertanian } \rightarrow \text { produk unggulan: } \\
\text { barang kerajinan dari kerang, } \\
\text { olahan makanan laut, beras } \\
\text { merah } \\
\text { d. Desa memiliki lahan sawah } \\
\text { dan hutan mangrove }\end{array}$ & 2 & $\begin{array}{ll}\text { a. Belum ada tindak lanjut } \\
\text { pembentukan BUM Desa } \\
\text { b. Belum ada sinergi antara } \\
\text { Kepala Desa dan BPD untuk } \\
\text { menyusun Perdes tentang } \\
\text { BUM Desa } \\
\text { c. Belum ada pengalaman dalam } \\
\text { merencanakan sebuah usah } \\
\text { d. Belum ada kerjasama dengan } \\
\text { pihak eksternal untuk } \\
\text { pengembangan desa, } \\
\text { terutama BUM Desa }\end{array}$ & 2 \\
\hline Rata-Rata & 2 & Rata-Rata & 1.75 \\
\hline Peluang-Opportinity (0) & Skor & Ancaman-Threat (T) & Skor \\
\hline $\begin{array}{ll}\text { a. } & \text { Perkembangan sektor } \\
& \text { pariwisata di Pulau Belitung } \\
\text { b. } & \text { Dukungan pemerintah dan } \\
\text { stakeholder lainnya }\end{array}$ & 2 & $\begin{array}{l}\text { a. Lokasi desa yang dekat } \\
\text { dengan perkotaan } \\
\text { menyebabkan banyaknya } \\
\text { pesaing usaha/ bisnis }\end{array}$ & 1 \\
\hline Rata-Rata & 2 & Rata-Rata & 1 \\
\hline
\end{tabular}

Rata-rata skor kemudian dimasukkan ke dalam perhitungan berikut.

$$
\begin{aligned}
& x=\frac{S-W}{2}=\frac{2-1.75}{2}=0.125 \\
& y=\frac{O-T}{2}=\frac{2-1}{2}=0.5
\end{aligned}
$$

Hasil perhitungan di atas menunjukkan bahwa titik koordinat pada sumbu matrik analisis SWOT adalah $\mathrm{x}=0.125$ dan $\mathrm{y}=0.5$. Hasil analisis tersebut dapat digambarkan dalam matrik (lihat gambar 1 ). Berdasarkan matrik pada gambar 1, maka diketahui bahwa strategi untuk pendirian BUM Desa di Desa Air Saga adalah menggunakan strategi agresif. Artinya, desa memiliki kekuatan dan memanfaatkan peluang untuk mendirikan BUM Desa. Berdasarkan tabel matrik, strategi agresif dilakukan dengan cara:

a. Menentukan bidang usaha yang berhubungan dengan sektor pariwisata yang bisa menjadi central untuk memasarkan produk unggulan desa yaitu agrowisata sawah dan hutan mangrove.

b. Memanfaatkan dukungan pemerintah dan stakeholder lainnya untuk membentuk BUM Desa.

Pada saat pelaksanaan FGD, Kepala Seksi Kesejahteraan Desa Air Saga mengungkapkan untuk segera memasukkan rencana pendirian BUM Desa dalam Rencana Pembangunan Jangka Menengah Desa (RPJM Desa) dan membangun sinergi untuk menyusun dasar hukum pendirian BUM Desa. Dari hasil FGD, terbentuk formula strategi pendirian BUM Desa yang disepakati bersama yaitu:

a. Memasukkan program pendirian BUM Desa dalam RPJM Desa tahun 2020. 
b. Persiapan pembentukaan BUM Desa dilaksanakan setelah terpilih dan ditetapkannya pengurus BPD baru (tahun 2019).

c. Membentuk tim persiapan pembentukanBUM Desa yang terdiri dari Kepala Desa, BPD, perwakilan tokoh masyarakat, perwakilan organisasi masyarakat. Tugas dari tim ini adalah menyusun perdes tentang BUM Desa, visi misi, AD/ART, dan mekanisme pemilihan pengurus BUM Desa.

d. Melibatkan pihak eksternal untuk mendampingi tim persiapan pembentukan BUM Desa dalam menyelesaikan tugasnya.

e. Melaksanakan musyawarah desa untuk mengesahkan perdes,AD/ART, dan pengurus BUM Desa.

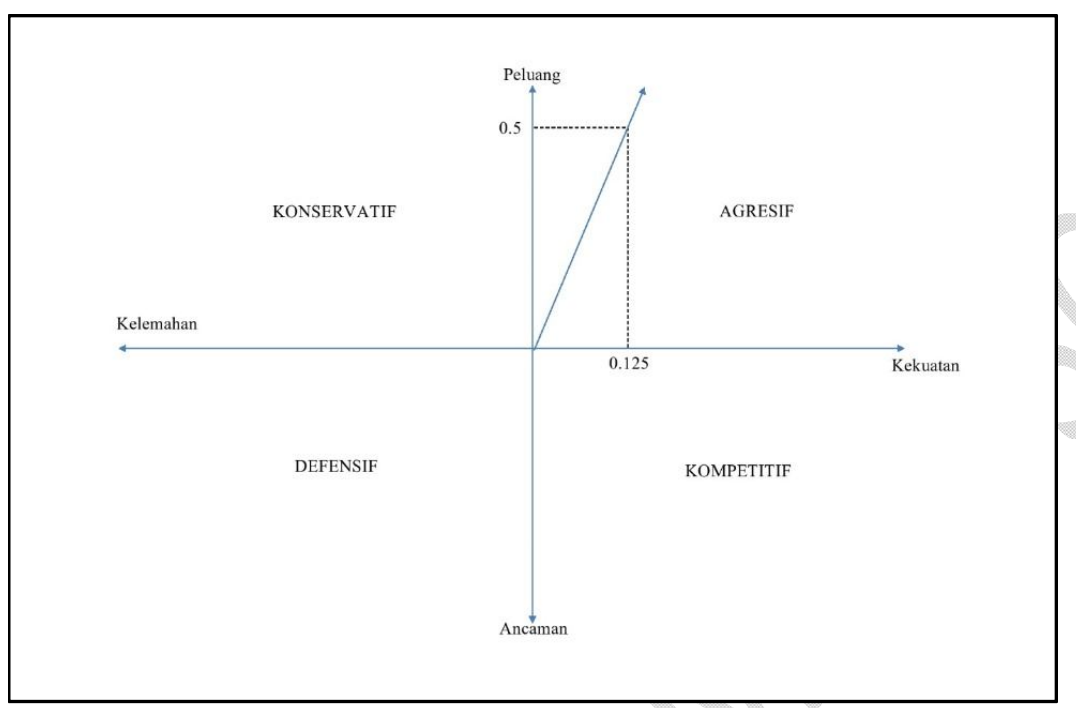

Gambar 1. Matrik Analisis SWOT

\section{Pelaksanaan Strategi Pembentukan BUM Desa}

Formula strategi pendirian BUM Desa harus segera dilaksanakan pada tahun 2020 sesuai dengan rencana dalam RPJM Desa. Mengingat kurangnya sinergi setiap elemen untuk pendirian BUM Desa maka perlu adanya pendampingan dari akademisi dan atau pemerintah. Informasi yang diperoleh dari berdesa.com (2015), Pemerintahan Desa bisa menggunakan pendamping desa yang memiliki tugas khusus di bidang pembangunan peluang usaha di desa. Masih pada sumber yang sama yaitu berdesa.com (2018), salah satu fungsi pendamping desa adalah fasilitasi pembentukan BUMDesa.

Pendampingan desa diatur dalan Peraturan Menteri Desa, Pembangunan Daerah Tertinggal, dan Transmigrasi Republik Indonesia Nomor 3 Tahun 2015 tentang Pendampingan Desa. Berdasarkan permendes tersebut dijelaskan bahwa pendampingan desa merupakan tindakan pemberdayaan masyarakat melalui asistensi, pengorganisasian, pengarahan dan fasilitas desa. Pihak yang bisa melakukan kegiatan pendampingan desa adalah tenaga pendampingan profesional, kader pemberdayaan masyarakat desa, dan atau pihak ketiga yaitu perguruan tinggi, lembaga swadaya masyarakat, organisasi kemasyarakatan, dan perusahaan. Jadi, desa bisa memanfaatkan salah satu dari ketiga jenis pendamping desa tersebut untuk persiapan pembentukan BUM Desa.

Berdasarkan informasi dari Kepala Desa, Pemerintahan Desa belum pernah mengajukan permohonan pendampingan dari tenaga ahli untuk mendirikan BUM Desa. Kepala bidang Pemberdayaan Desa juga mengatakan hal yang sama bahwa Desa Air Saga belum pernah berokordinasi dengan tenaga ahli maupun kepala bidang pemberdayaan desa untuk merencanakan 
pembentukan BUM Desa. Oleh sebab itu, pendampingan desa perlu dilakukan supaya strategi yang telah disusun dapat dilaksanakan dengan baik.

\section{Evaluasi Pelaksanaan Strategi Pembentukan BUM Desa}

Evaluasi pelaksanaan strategi pembentukan BUM Desa dilakukan dengan membandingkan ketercapaian pelaksanaan strategi pendirian BUM Desa dengan hasil yang diinginkan. Evaluasi dilakukan pada setiap kegiatan yang dilakukan oleh tim persiapan pembentukanBUM Desa. Menurut Farida Yusuf (2000), ada dua fungsi evaluasi yaitu formatif dan sumatif. Fungsi formatif digunakan untuk memperbaiki dan mengembangkan kegiatan yang sedang berlangsung, sedangkan fungsi sumatif mengarah pada keputusan tentang kelanjutan program berhenti atau diteruskan. Evaluasi pelaksanaan strategi pendirian BUM Desa dilakukan dengan untuk perbaikan dan pengembangan kegiatan yang sedang berlangsung sehingga memiliki fungsi sumatif.

\section{KESIMPULAN}

\section{Kesimpulan}

Strategi manajemen pembentukan BUM Desa dilakukan dengan memetakan kekuatan, kelemahan, peluang, dan ancaman. Hasil dari analisis SWOT diketahui bahwa strategi agresif adalah strategi yang tepat untuk membentuk BUM Desa di Desa Air Saga Kecamatan Tanjungpandan Kabupaten Belitung. Pelaksanaan pembentukan BUM Desa harus melibatkan pendamping desa dan dievaluasi dalam setiap kegiatannya.

\section{Implikasi Praktis / Teoritis}

Berdasarkan kesimpulan yang diperoleh, bahwa implikasi dari hasil penelitian adalah pembentukan BUM Desa akan lebih mudah diwujudkan dengan menerapkan strategi manajemen yang telah dirumuskan dari hasil penelitian. Hal yang harus diperhatikan oleh desa adalah keterlibatan pendamping desa baik dari akademisi maupun dari pendamping desa yang ditetapkan oleh pemerintah.

\section{Keterbasan dan Saran}

Penelitian ini memiliki keterbatasan yaitu minimnya informasi tentang ancaman pada kegiatan analisis lingkungan. Keterbatasan ini disebabkan oleh minimnya sumber informasi yaitu hanya dengan melakukan wawancara kepada kepala desa. Oleh sebab itu, perlu penjajakan lebih jauh dengan menggunakan berbagai metode yang tepat untuk mengumpulkan data tentang ancaman misalnya menggunakan kuesioner yang disebarkan pada saat melakukan FGD dengan masyarakat desa.

\section{REFERENSI}

Asvi, Zul. (2017). Manajemen Badan Usaha Milik Desa (BUMDES) Bina Usaha Desa Kepenuhan Barat Kecamatan Kepenuhan Kabupaten Rokan Hulu. Jurnal JOM FISIP Vol.4, No.2, Hal.115.https://jom.unri.ac.id/index.php/JOMFSIP/ article/ view/15940

Budiono, P. (2015). Implementasi Kebijakan Badan Usaha Milik Desa (Bumdes) di Bojonegoro (Studi di Desa Ngringinrejo Kecamatan Kalitidu dan Desa Kedungprimpen Kecamatan Kanor). Jurnal Politik Muda, Vol.4 No.1, Hal.116-125. http:// journal.unair.ac.id/JPM@implementasikebijakan-badan-usaha-milik-desa-(bumdes)-di-bojonegoro-(studi-di-desa-ngringinrejokecamatan-kalitidu-dan-desa-kedungprimpen-kecamatan-kanor)-article-8689-media-80category-8.html

Berdesa.com. (2015). Uraian Tugas Pendamping Desa. Diunduh pada tanggal 10 September 2019 dari http:// www.berdesa.com/ apa-saja-harus-dilakukan-pendamping-desa/ 
Berdesa.com. 2018. Apa Saja yang Harus Dilakukan Pendamping Desa. Diunduh pada tanggal 10 September 2019 dari http:// www.berdesa.com/ apa-saja-harus-dilakukan-pendampingdesa/

Gunanto, E. Y. A et al. (2016). Pengembangan Desa mandiri Melalui Pengelolaan Badan Usaha Milik Desa (BUMDes). Jurnal Dinamika Ekonomi dan Bisnis. Vol.13, No.1, Hal.67-81. https:// ejournal.unisnu.ac.id/JDEB/article/view/395

Hasibuan, M.S.P. (2009). Manajemen Dasar, Pengertian dan Masalah.Jakarta: Bumi Aksara

Hayyuna, R et al. (2014). Strategi Manajemen Aset Bumdes dalam Rangka Meningkatkan Pendapatan Desa (Studi paa BUMDES di desa Sekapuk, Kecamatan Ujungpangkah, Kabupaten Gresik). Jurnal Administrasi Publik (JAP), Vol.2,No.1,Hal.1http://administrasipublik.studentjournal.ub.ac.id/ index.php/jap/article/view/ 330

Murdani, A. D. (2017). Potensi Desa. Diunduh dari https:/ / portal- ilmu.com/ pengertian-potensidesa/ pada tanggal 23 Agustus 2018

Peraturan Pemerintah No.72 Tahun 2005 tentang Desa

Peraturan Menteri dalam Negeri No.39 Tahun 2010 tentang BUM Desa

Peraturan Menteri Desa, Pembangunan Daerah Tertinggal, dan Transmigrasi Republik Indonesia Nomor 4 Tahun 2015 tentang Pendirian, Pengurusan dan Pengelolaan, dan Pembubaran Badan Usaha Milik Desa.

Peraturan Menteri Desa, Pembangunan Daerah Tertinggal, dan Transmigrasi Republik Indonesia Nomor 3 Tahun 2015 tentang Pendampingan Desa

Siswanto, B. (2005). Manajemen Tenaga Kerja Indonesia Pendekatan Administratif dan Operasional. Jakarta: PT Bumi Aksara.

Sule, E. T \& Saefullah, K (2015). Pengantar Manajemen. Jakarta: Prenadamedia Group.

Sugiyono (2013). Metode Penelitian Kombinasi (Mixed Methodes). Bandung: Alfabeta.

Undang-Undang No.32 Tahun 2004 tentang Pemerintahan Daerah.

Yusuf, Fa. (2000). Evaluasi Program. Jakarta: PT Rinek Cipta.

\section{PROFIL PENULIS}

Eka Nuraini adalah dosen tetap Prodi Manajemen Administrasidengan pengalaman mengajar Metotologi Penelitian, Kepemimpinan, Ilmu Kealaman Dasar, Ilmu Sosial Dasar. Penulis memiliki ketertarikan pada penelitian manajemen dan pendidikan.

Djunaedi Djafar adalah dosen tetap Prodi Manajemen Administasi dengan pengalaman mengajar Statistik Deskriptif, Pengantar Bisnis, Bank dan Lembaga Keuangan. Penulis memiliki ketertarikan pada penelitian manajemen bisnis.

Hartian Ramadhanadalah dosen tetap Prodi Manajemen Administrasidengan pengalaman mengajarSistem Informasi Manajemen, Pengantar Manajemen, Komunikasi Bisnis, dan Kewirausahaan. Penulis memiliki ketertarikan pada penelitian manajemen bisnis dan sistem informasi manajemen. 
This page intention to blank

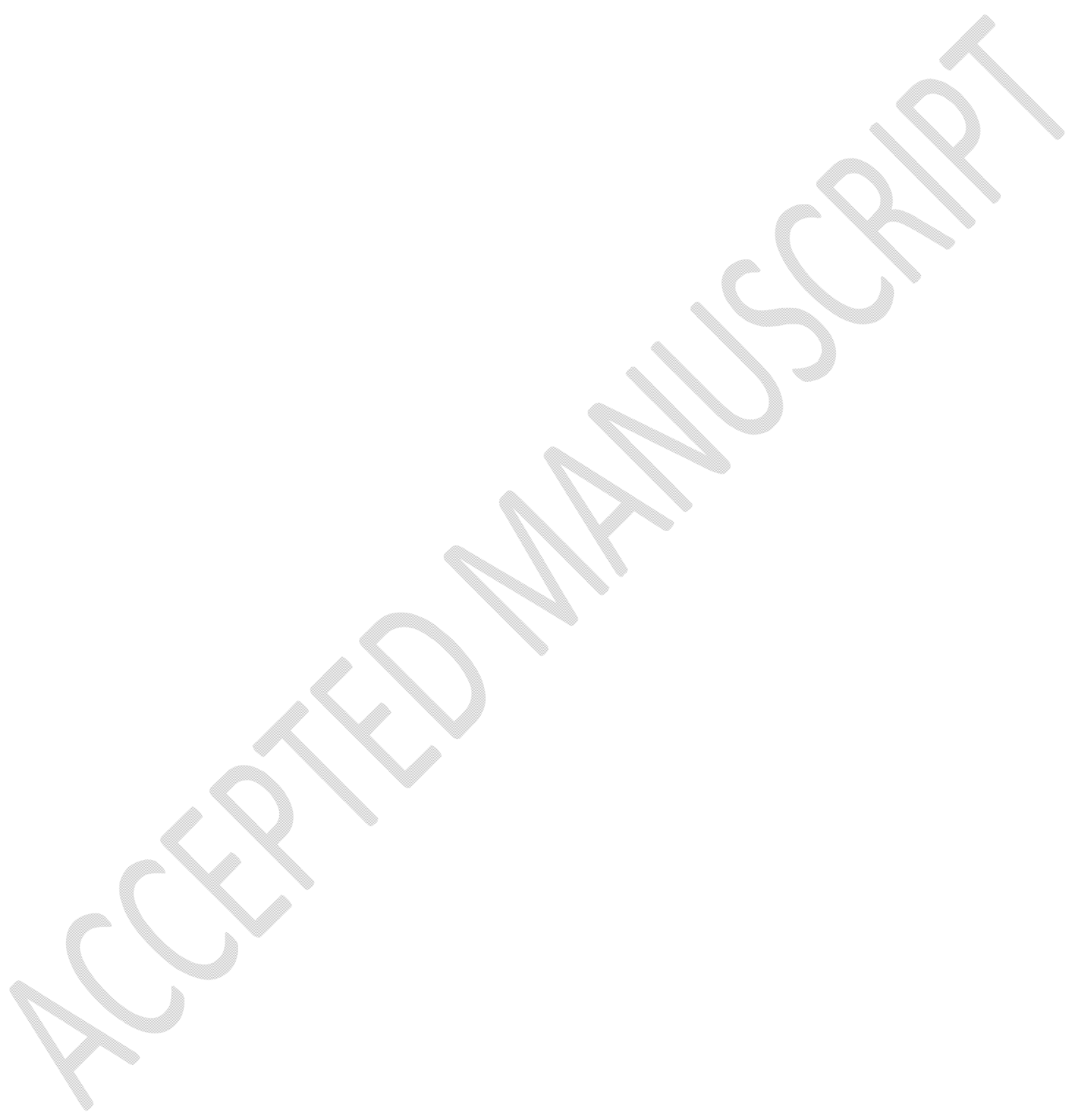

